\title{
Evaluation of the implementation of the directly observed treatment strategy for tuberculosis in a large city
}

\author{
Avaliação da implantação da estratégia de tratamento diretamente \\ observado para tuberculose em um município de grande porte \\ Evaluación de la implantación de la estrategia de tratamiento directamente \\ observado para tuberculosis en un municipio de gran porte
}

Débora Cristina Brasil da Silva Lavôr ${ }^{1}$, Jair dos Santos Pinheiro², Maria Jacirema Ferreira Gonçalves ${ }^{1,3}$

How to cite this article:

Lavôr DCBS, Pinheiro JS, Gonçalves MJF. Evaluation of the implementation of the directly observed treatment strategy for tuberculosis in a large city. Rev Esc Enferm USP. 2016;50(2):245-252. DOI: http://dx.doi.org/10.1590/S0080-623420160000200010

${ }^{1}$ Universidade Federal do Amazonas, Escola de Enfermagem, Manaus, AM, Brazil.

${ }^{2}$ Fundação de Vigilância em Saúde do Amazonas, Secretaria Municipal de Saúde de Manaus, Manaus, AM, Brazil.

${ }^{3}$ Fundação Oswaldo Cruz, Instituto Leônidas e Maria Deane, Manaus, AM, Brazil.

\begin{abstract}
Objective: To assess the degree of implementation of the Directly Observed Treatment, Short-course - DOTS for tuberculosis (TB) in a large city. Method: Assessment of the implementation of the logic model, whose new cases of infectious pulmonary TB were recruited from specialized clinics and followed-up in basic health units. The judgment matrix covering the five components of the DOTS strategy were used. Results: The result of the logic model indicates DOTS was partially implemented. In external, organizational and implementation contexts, the DOTS strategy was partially implemented; and, the effectiveness was not implemented. Conclusion: The partial implementation of the DOTS strategy in the city of Manaus did not reflect in TB control compliance, leading to low effectiveness of the program.
\end{abstract}

\section{DESCRIPTORS}

Tuberculosis; Directly Observed Therapy; Health Evaluation; Program Evaluation; Public Health Nursing. 


\section{INTRODUCTION}

Tuberculosis (TB) is an infectious disease caused by Mycobacterium tuberculosis, but its determination is not only biological, and therefore, its control requires multiple strategies ${ }^{(1)}$. The disease is characterized by an insidious onset, whose treatment lasts at least six months, which is relatively long and difficult to achieve results through the control program, namely: an increase of cure rate (above $85 \%$ ) and low percentage of treatment default (below 5\%) (2). For this, the recommendation is the decentralization of the program for primary care (PC) of the cities, as well as supervised treatment ${ }^{(2)}$. In Brazil, in 2012, the average percentage of treatment default and cure were, respectively, $10.5 \%$ and $70.6 \%{ }^{(3)}$, the highest incidence rates are in the states of Rio de Janeiro and Amazonas. In Amazonas, the city of Manaus, with an estimated population of $1,982.177$ inhabitants in 2013 , accounts for about $70 \%$ of state cases, with a cure rate of $70.8 \%$ and $16.7 \%$ treatment default in the year $2013^{(3)}$ revealing the severity of the TB problem in a large city.

The Directly Observed Treatment, Short-course DOTS, recommended by the World Health Organization (WHO), is based on five fundamental components: sustained political and financial commitment; diagnosis through quality ensured sputum-smear microscopy; standardized short-course anti-TB treatment given under direct and supportive observation (DOT); a management system for uninterrupted supply of anti-TB drugs; information system that allow monitoring and evaluation of actions and their impacts ${ }^{(4)}$.

Some studies have pointed out the benefits of DOTS strategy in the success of the program ${ }^{(4-6)}$, but lack evaluations of this strategy in the Amazon scenario noted above with high incidence, as well as the need to investigate the performance of DOTS in loco, and not only through record in the information system. Therefore, it is important to evaluate the implementation of DOTS, as it is only with its implementation that we may measure its impact on the effectiveness of the program. The objective of this study is to assess the degree of implementation of the directly observed treatment strategy for TB in a large city.

\section{METHOD}

Implementation evaluation was performed through multiple case studies of 22 Basic Health Units (BHU) and four specialized clinics in the city of Manaus, with imbricated levels of analysis using the Matrix Analysis and Judgment based on the Evaluation Logic Model, adapted from a proposal for evaluation of the Program for Tuberculosis Control (PTC) $)^{(7)}$. Figure 1 shows the evaluation logic model. The left column shows the components that serve as input or support for the activities, and the right column display the products and outcomes, which the evaluation allows us to identify the degree of implementation. The components of the model are the essential elements for the operationalization of the strategy, according to the guidelines of the National Program for Tuberculosis Control (NPTC) $)^{(2,8)}$. This logic model was structured based on the principles that guide the operation of the NPTC, and its formulation does not show directly the study variables, but the theoretical components necessary to TB control. For the analysis, these components, from the Evaluation Logic Model, are presented in the following dimensions: external context, organizational context, implementation context and context of the effectiveness of DOTS Strategy.

The evaluation of the Program for TB control occurred in 22 Basic Health Units (BHU) and four reference outpatient clinics, called polyclinics specialties, which reported cases under DOTS treatment in 2012. The study was approved by the Research Ethics Committee involving Human Subjects (CAAE No 01374412.8.0000.5020) and the data were collected from October to December 2013, participants signed an Informed Consent form.

The collection of primary data occurred through interviews with nurses and secondary data from the following sources: record book of symptomatic respiratory patients, record book and monitoring of TB cases, patient charts, directly observed treatment form and monthly report activity. The recording of data occurred in a structured instrument as each item of the judgment matrix, with double entry typing and analysis in STATA 9.0 software.

The judgement matrix is presented in the results tables, separated by dimension, in order to facilitate reading. Each dimension was subdivided into categories called the sub-dimensions, considering the program components that lead to resoluteness of TB control actions. Therefore, indicators were created to judge the level of implementation of the DOTS strategy in the PTC.

The maximum score for each context was distributed as follows: external context -20 points; organizational context -45 points; context of implementation -65 points; context of effectiveness -70 points. Therefore, the maximum possible value was the total of 200 points, and the results were presented in percentage ( $\Sigma$ points observed/ maximum points*100). This score, when calculating the sub dimension and context, consider the maximum possible points in each calculated compartment. The maximum score was determined by the importance of each element of DOTS strategy implemented ${ }^{(7)}$. The score refers to what was recorded in the collection of data on each item. As these are data from several BHU, the displayed values relate to the mean of the city of Manaus.

The cutoff points established to define the degree of implementation of the DOTS strategy for TB were distributed according to the percentage of the maximum score achieved in relation to the expected total score of each sub-dimension, dimension and the whole set of data: $<40 \%$ - Not implemented; $\geq 40 \%$ to $<75 \%$ - Partially implemented; $\geq 75 \%$ - Implemented. 


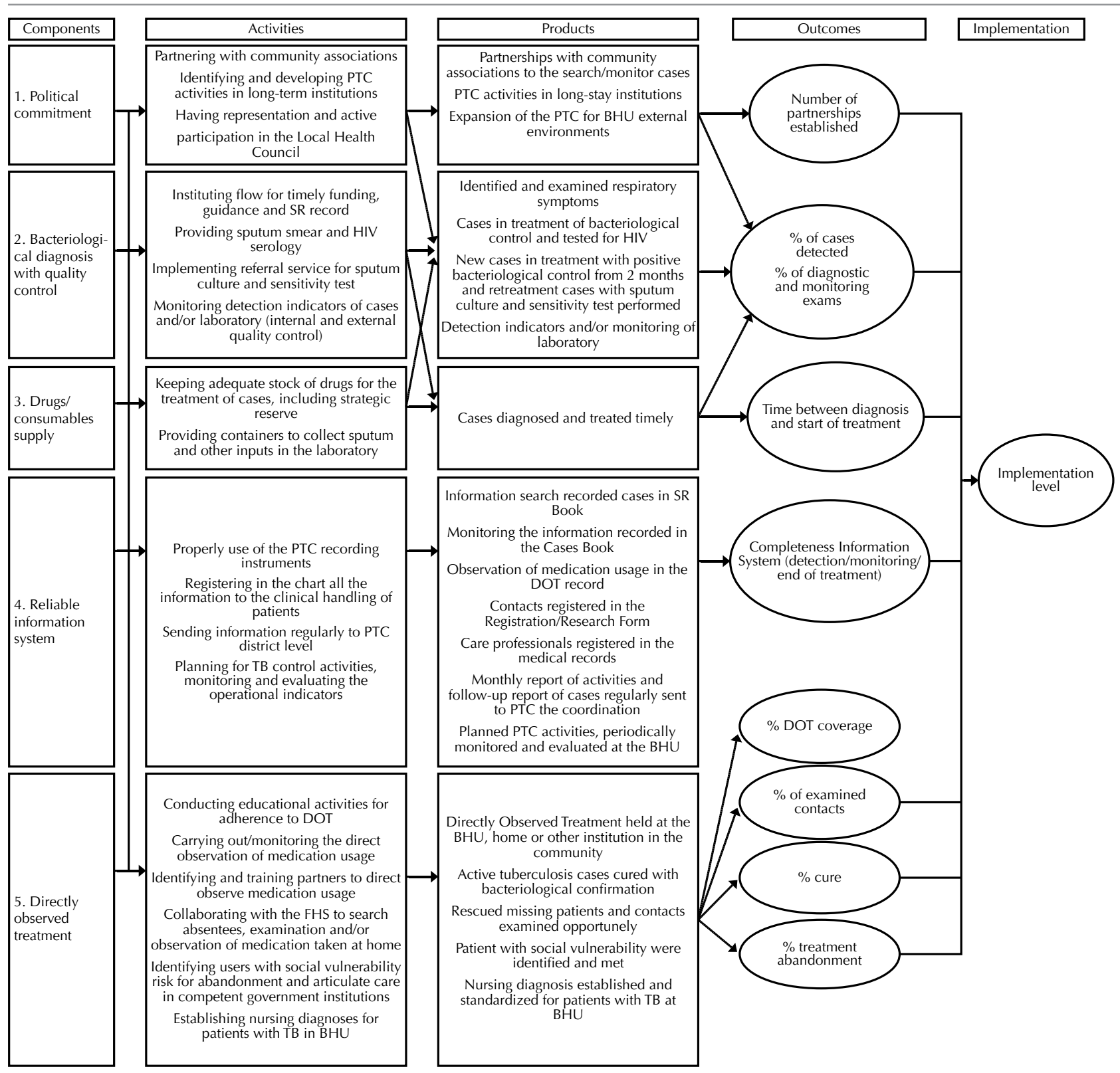

Adapted from a proposed evaluation of the Program for Tuberculosis $\mathrm{Control}^{(7)}$.

Note: DOT - Directly Observed Treatment. PTC - Program for Tuberculosis Control. FHS - Family Health Strategy. BHU - Basic Health Unit. TB - Tuberculosis. SR Symptomatic Respiratory. HIV - Human Immunodeficiency Virus.

Figure 1 - Logic Model of Directly Observed Treatment, Short-course for Tuberculosis.

\section{RESULTS}

In the external context (Table 1), we have the following sub-dimensions: institutional vulnerability (partially implemented - 48.7\%), political commitment (not implemented $-39.6 \%)$ and social and individual vulnerabilities. The latter sub-dimension comprises the proportion of patients with social register performed; and proportion of patients with social register held and which presents social determinant of risk for treatment default; and proportion of patients with received care of the social determinant of risk for treatment default. However, there was no data available in health services on these indicators.

In the organizational context (Table 2), we evaluated the sub-dimensions: technical, political and financial autonomy (partially implemented - 65.4\%), inter-programmatic actions (partly implemented - 63.9\%), the PTC management (partially implemented $-49.2 \%$ ), and information system (implemented - 79.8\%).

In the implementation context (Table 3), we evaluated the implementation and coverage of the DOTS strategy (not implemented - 26.7\%), bacteriological diagnosis (partially implemented $-73.3 \%$ ), supply of medicines and/or consumables (partially implemented - 70.0\%) and integrality (partially implemented $-65.0 \%$ ).

For the effectiveness context (Table 4), we evaluated the outcome of treatment, referring to cure and treatment default (not implemented - 39.1\%).

In the set of all contexts (all dimensions), it was identified that DOTS strategy in the city of Manaus, in the year 2012, the classification was partially implemented (74.7\%). 
Table 1 - Judge Matrix: dimension external context of the DOTS* strategy assessment of implementation in Primary Health Care Manaus, Amazonas, 2012.

\begin{tabular}{|c|c|c|c|c|}
\hline $\begin{array}{l}\text { Components } \\
\text { (sub-dimensions) }\end{array}$ & Indicators (maximum score) & $\begin{array}{l}\text { Score } \\
\text { (mean) }\end{array}$ & $\begin{array}{l}\text { Dimensions score (\%) } \\
\text { Min; Med; Max }\end{array}$ & $\begin{array}{l}\text { Implementation } \\
\text { degree }\end{array}$ \\
\hline \multirow{3}{*}{$\begin{array}{l}\text { Institutional } \\
\text { vulnerability } \\
\text { ( } 3 \text { points) }\end{array}$} & $\begin{array}{l}\text { Existence of institutions like day care centers, nursing homes, } \\
\text { hostels, and/or prisons in the territory of the basic health unit (1) }\end{array}$ & 0.0 & \multirow{3}{*}{$0.0 ; 48.7 ; 100.0$} & \multirow{3}{*}{$\begin{array}{c}\text { Partially } \\
\text { implemented }\end{array}$} \\
\hline & $\begin{array}{c}\text { Existence of partnership with community associations and civil } \\
\text { society organizations (1) }\end{array}$ & 0.8 & & \\
\hline & Representation in the Local Health Council (1) & 0.5 & & \\
\hline \multirow{4}{*}{$\begin{array}{l}\text { Political } \\
\text { commitment } \\
\text { (10 points) }\end{array}$} & Participation in the meetings of Local Health Council (2) & 0.3 & \multirow{4}{*}{$0.0 ; 39.6 ; 100.0$} & \multirow{4}{*}{$\begin{array}{l}\text { Not } \\
\text { implemented }\end{array}$} \\
\hline & $\begin{array}{l}\text { Participates in the programming consumables for operationalization } \\
\text { of DOTS in basic health unit (water, glass, DOTS form) (2) }\end{array}$ & 1.2 & & \\
\hline & $\begin{array}{l}\text { Rearranges the service for location and observe the medication } \\
\text { usage by the patient (3) }\end{array}$ & 1.0 & & \\
\hline & Sets rules and routines for the operationalization of DOTS (3) & 1.3 & & \\
\hline \multirow{3}{*}{$\begin{array}{l}\text { Social and } \\
\text { individual } \\
\text { vulnerability } \\
\text { (7 points) }\end{array}$} & Proportion of patients with social register performed (2) & 2.0 & \multirow{3}{*}{$* *$} & \\
\hline & $\begin{array}{l}\text { Proportion of patients with social register performed that presents } \\
\text { social determinant of risk for treatment default }(2)\end{array}$ & 2.0 & & \\
\hline & $\begin{array}{l}\text { Proportion of patients with received care of social risk determinant } \\
\text { for treatment default (3) }\end{array}$ & 3.0 & & \\
\hline
\end{tabular}

*DOTS: Directly Observed Treatment, Short-course.

**No data available in the data collection sites. Held only to identify which were contained in the proposed matrix. In their score, total points were considered.

Table 2 - Judge Matrix: organizational context dimensions for assessing the implementation of the DOTS* strategy in primary health care - Manaus, Amazonas, 2012.

\begin{tabular}{|c|c|c|c|c|}
\hline $\begin{array}{l}\text { Components } \\
\text { (sub-dimensions) }\end{array}$ & Indicators (maximum score) & $\begin{array}{l}\text { Score } \\
\text { (mean) }\end{array}$ & $\begin{array}{l}\text { Dimensions score (\%) } \\
\text { Min; Med; Max }\end{array}$ & $\begin{array}{l}\text { Implementation } \\
\text { degree }\end{array}$ \\
\hline \multirow{3}{*}{$\begin{array}{l}\text { Technical, political } \\
\text { and financial } \\
\text { autonomy ( } 6 \text { points) }\end{array}$} & $\begin{array}{c}\text { Participation in the control of complementary incentives to } \\
\text { DOTS (food aid/ transport) (2) }\end{array}$ & 0.3 & \multirow{3}{*}{$33.3 ; 65.3 ; 100.0$} & \multirow{3}{*}{$\begin{array}{c}\text { Partially } \\
\text { implemented }\end{array}$} \\
\hline & $\begin{array}{c}\text { Performs planning of TB control actions (assistance } \\
\text { parameters) (2) }\end{array}$ & 1.6 & & \\
\hline & Performs adjustment in programmed actions (2) & 1.9 & & \\
\hline \multirow{3}{*}{$\begin{array}{l}\text { Inter-programmatic } \\
\text { actions } \\
\text { (8 points) }\end{array}$} & Promotes the integration of PTC with the laboratory sector (2) & 1.6 & \multirow{3}{*}{$0.0 ; 63.9 ; 100.0$} & \multirow{3}{*}{$\begin{array}{l}\text { Partially } \\
\text { implemented }\end{array}$} \\
\hline & $\begin{array}{c}\text { Promotes the integration of PTC with the STD/AIDS } \\
\text { program (2) }\end{array}$ & 1.6 & & \\
\hline & $\begin{array}{l}\text { Promotes the integration of PTC with the Social Services } \\
\text { sector (number of consultations) (4) }\end{array}$ & 1.8 & & \\
\hline \multirow{4}{*}{$\begin{array}{l}\text { Management of the } \\
\text { PTC ( } 15 \text { points })\end{array}$} & Nursing work time in the PTC (5) & 3.3 & \multirow{4}{*}{$13.3 ; 49.2 ; 80.0$} & \multirow{4}{*}{$\begin{array}{l}\text { Partially } \\
\text { implemented }\end{array}$} \\
\hline & Time of the last training/ update on DOTS (2) & 1.8 & & \\
\hline & $\begin{array}{l}\text { Promotes integration of PTC with FHS teams in the scope of } \\
\qquad \text { BHU (3) }\end{array}$ & 1.8 & & \\
\hline & $\begin{array}{l}\text { Monitors/evaluates the major TB indicators in the BHU (pact, } \\
\text { PHSA, SR identified and examined, identification BK+ cases, } \\
\text { HIV testing, TB treatment cohort - all forms) (5) }\end{array}$ & 0.3 & & \\
\hline \multirow{5}{*}{$\begin{array}{l}\text { Information system } \\
\text { (16 points) }\end{array}$} & Properly record information on SR Registry Book (2) & 0.9 & \multirow{5}{*}{$56.2 ; 79.8 ; 100.0$} & \multirow{5}{*}{ Implemented } \\
\hline & Properly register information on Case Registration Book (2) & 1.5 & & \\
\hline & Properly register information on Case Monitoring Bulletin (2) & 1.5 & & \\
\hline & The closure of the new TB cases - all reported forms (6) & 5.5 & & \\
\hline & $\begin{array}{c}\text { Send regular Monthly Report of Activities/ Case Monitoring } \\
\text { Bulletin (4) }\end{array}$ & 3.1 & & \\
\hline
\end{tabular}

*DOTS: Directly Observed Treatment, Short-course; TB: Tuberculosis; PTC Program for Tuberculosis Control; STD: Sexually Transmitted Diseases; AIDS: Acquired Immunodeficiency Syndrome; FHS: Family Health Strategy; BHU: Basic Health Unit; PHSA: Programming Of Health Surveillance Actions; SR: Symptomatic Respiratory; BK: bacillus Koch. 
Table 3 - Judge Matrix: dimension of evaluation of the implementation context of DOTS* strategy in primary health care - Manaus, Amazonas, 2012.

\begin{tabular}{|c|c|c|c|c|}
\hline $\begin{array}{l}\text { Components } \\
\text { (sub-dimensions) }\end{array}$ & Indicators (maximum score) & $\begin{array}{l}\text { Score } \\
\text { (mean) }\end{array}$ & $\begin{array}{l}\text { Dimensions score (\%) } \\
\text { Min; Med; Max }\end{array}$ & $\begin{array}{l}\text { Implementation } \\
\text { degree }\end{array}$ \\
\hline \multirow{4}{*}{$\begin{array}{l}\text { Operation and } \\
\text { Coverage of } \\
\text { DOTS ( } 30 \text { points) }\end{array}$} & $\begin{array}{l}\text { Performs and records the direct observation of medication } \\
\text { use in the } 1^{\text {st }} \text { phase of the treatment }(10)\end{array}$ & 3.5 & \multirow{4}{*}{$26.7 ; 26.7 ; 70.0$} & \multirow{4}{*}{$\begin{array}{c}\text { Not } \\
\text { implemented }\end{array}$} \\
\hline & $\begin{array}{l}\text { Performs and records the direct observation of medication } \\
\text { use in the } 2^{\text {nd }} \text { phase of treatment }(8)\end{array}$ & 3.2 & & \\
\hline & Proportion of new smear positive cases in DOTS (7) & 2.8 & & \\
\hline & Implements search for absentees, including FSH support (5) & 0.0 & & \\
\hline \multirow{5}{*}{$\begin{array}{l}\text { Bacteriological } \\
\text { diagnosis ( } 15 \text { points) }\end{array}$} & Performs case finding (3) & 1.2 & \multirow{5}{*}{$33.3 ; 73.3 ; 100.0$} & \multirow{5}{*}{$\begin{array}{l}\text { Partially } \\
\text { implemented }\end{array}$} \\
\hline & Register and examines contacts (3) & 2.2 & & \\
\hline & Performs smear for follow-up treatment (3) & 3.0 & & \\
\hline & Performs HIV serology test (3) & 2.0 & & \\
\hline & Performs sputum culture for cases of TB retreatment (3) & 2.4 & & \\
\hline \multirow{3}{*}{$\begin{array}{l}\text { Supply of drugs/ } \\
\text { consumables } \\
\text { (10 points) }\end{array}$} & $\begin{array}{l}\text { Inventory existence of medicine that meets the cases under } \\
\text { treatment (3) }\end{array}$ & 2.0 & \multirow{3}{*}{$30.0 ; 70.0 ; 100.0$} & \multirow{3}{*}{$\begin{array}{c}\text { Partially } \\
\text { implemented }\end{array}$} \\
\hline & Container available for sputum collection (4) & 3.8 & & \\
\hline & $\begin{array}{l}\text { Offers laboratory supplies (staining, slides, masks, etc.) that } \\
\text { meets the needs of } \mathrm{BHU}(3)\end{array}$ & 1.1 & & \\
\hline \multirow{3}{*}{$\begin{array}{l}\text { Integrality } \\
\text { (10 points) }\end{array}$} & $\begin{array}{l}\text { Implement the reference cases with diseases and/or } \\
\text { complications associated or not with TB (2) }\end{array}$ & 0.4 & \multirow{3}{*}{$0.0 ; 65.0 ; 90.0$} & \multirow{3}{*}{$\begin{array}{c}\text { Partially } \\
\text { implemented }\end{array}$} \\
\hline & Medical consultation for patients with TB (4) & 2.5 & & \\
\hline & Nursing consultation for patients with TB (4) & 3.1 & & \\
\hline
\end{tabular}

*DOTS: Directly Observed Treatment, Short-course; TB: Tuberculosis; HIV: Human Immunodeficiency Virus; FHS: Family Health Strategy; BHU: Basic Health Unit.

Table 4 - Judge Matrix: dimension of effectiveness context for assessment of the implementation of the DOTS* strategy in primary health care - Manaus, Amazonas, 2012.

\begin{tabular}{|c|c|c|c|c|}
\hline $\begin{array}{l}\text { Components } \\
\text { (sub-dimensions) }\end{array}$ & Indicators (maximum score) & $\begin{array}{c}\text { Score } \\
\text { (mean) }\end{array}$ & $\begin{array}{l}\text { Dimensions score (\%) } \\
\text { Min; Med; Max }\end{array}$ & $\begin{array}{c}\text { Implementation } \\
\text { degree }\end{array}$ \\
\hline \multirow{9}{*}{$\begin{array}{l}\text { Treatment } \\
\text { Outcome } \\
\text { (70 points) }\end{array}$} & Cure rate of new smear positive cases in DOTS (10) & 6.6 & \multirow{9}{*}{$14.2 ; 39.0 ; 77.1$} & \multirow{9}{*}{$\begin{array}{l}\text { Not } \\
\text { implemented }\end{array}$} \\
\hline & Treatment default rate of new smear positive cases in DOTS (10) & 3.2 & & \\
\hline & $\begin{array}{c}\text { Cure rate of new smear positive cases in self-administered } \\
\text { treatment (6) }\end{array}$ & 0.3 & & \\
\hline & $\begin{array}{l}\text { Treatment default rate of new smear positive cases in self- } \\
\text { administered treatment }(6)\end{array}$ & 3.6 & & \\
\hline & Proven cure rate of new smear positive cases (6) & 1.5 & & \\
\hline & Cure rate of new smear positive cases (10) & 1.3 & & \\
\hline & Treatment default rate of new smear positive cases (10) & 5.5 & & \\
\hline & Cure rate of new TB cases - all forms (6) & 0.7 & & \\
\hline & Treatment default rate of new TB cases - all forms (6) & 4.2 & & \\
\hline
\end{tabular}

*DOTS: Directly Observed Treatment, Short-course; TB: Tuberculosis.

\section{DISCUSSION}

The results of this evaluative research show the situation of the program for tuberculosis control, to take into account the context in which the program operates. Since there is criticism of the directly observed treatment alone ${ }^{(9-11)}$, we analyzed the DOTS strategy as a whole, and therefore, an implementation evaluation was obtained, on which one can discuss and identify the strengths and limitations for the success of the strategy.

An important evaluation item is to identify the program's context ${ }^{(7)}$, since it can influence both the program implementation as its effectiveness ${ }^{(12)}$. We need to check the existence of the network services, long term care facilities and program interfaces with other departments and organizations of civil society ${ }^{(2)}$. Regarding the external environment, which describes the local situation, it was observed the disarticulation of the program with society and with the other institutions, although sub-dimension institutional vulnerability is partially implemented.

In sub-dimension political commitment (not implemented), the indicators, except for participation in programming consumables, not even reached $50 \%$ of the maximum score being as worst criterion the absence of participation in the Local Health Council, and even found the absence 
of Local Health Council in some units. This shows that political organization in the implementation of the DOTS strategy is impaired and weakened by its implementation. A mobilized community partners with health workers can be organized in support of a cause and build their own strategies of actions to strengthen public health policies, through the inclusion in the formal social control agencies ${ }^{(13)}$.

The lack of data on sub-dimension social and individual vulnerability indicates that this is a secondary subject. This can influence the success of the program and the DOTS strategy "given that TB is a disease of an eminently social nature, its persistence comes from inadequate social conditions and inequities and its control requires an understanding of the disease from a broad perspective, involving the social determination and overcoming result from the elimination of social inequalities" ${ }^{\prime(1)}$.

Regarding the organizational context (partially implemented), we observed the prioritizing programmatic actions to the detriment of technical, political and financial autonomy, participation in the control of complementary incentives of DOTS, with transportation assistance and/or food aid. However, not enough enforcement actions alone ${ }^{(10)}$, the involvement of health workers in the service organization is necessary ${ }^{(14)}$. In inter-programmatic actions there is deficit of PTC integration with other areas, especially social services, with a percentage of consultations less than $50 \%$ of expected, reflecting the lack of interdisciplinary, which has recognized value in $\mathrm{TB}$ control ${ }^{(15)}$.

As for the managerial aspects of the PTC, the monitoring deficiencies and assessment of the main indicators of TB affects the own assessment for decision-making, as in services is essential to use the monitoring indicators in daily life $\mathrm{e}^{(7,13)}$. Although the results indicate that professionals participated in updating activities, and work for at least one year in the program, there is no reflection in the implementation of the DOTS strategy, as one would expect a gain in quality of actions ${ }^{(13)}$. Apparently, the priority is the fulfillment of data population standards for the information system, which was classified as implemented, with remarkable records book in case of follow-up, although there are record deficiency in symptomatic respiratory infection book registry. However, we detect problems as the end of treatment of the cases because of the difficulty in understanding some professionals between cure and completing treatment, referring to the need for continuing education and not just specific training in service ${ }^{(7,15-16)}$.

The operation and DOTS coverage was the sub-dimension evaluated as the most deficient, classified as not implemented, since the records and observation of the medication are almost nonexistent, whether in the first or second phase of treatment. We question this situation, since it is the sub-dimension that expresses the implementation of the key element of the DOTS strategy ${ }^{(2,8)}$. Thus, if the directly observed treatment is only recorded in the information system, but locally does not reflect its implementation, we must think about the procedural phase, which should include monitoring of cases. Another problem is that no implementation of search of the absent treatment, either for lack of human resources, or the difficulty of communication to make contact by telephone with the absent patient or transport availability to get home. Nurses of the BHU report no integration of PTC with the Family Health Strategy in the search and case monitoring and, when it occurs, is informal, for individual initiative, contrary guideline from the Ministry of Health for the integration of services ${ }^{(17)}$.

In bacteriological diagnosis, classification was implemented partially. Only bacilloscopies for follow-up treatment are carried out in 100\% of BHU. The HIV serology test is difficult because there is no laboratory in some of the $\mathrm{BHU}$ and professional misconduct trained and qualified to perform rapid testing. In cases of retreatment found, sputum culture is performed in $80 \%$ of the health services. The availability of laboratory resources is an important element in the detection and monitoring of cases and its absence imposes additional work and barriers to treatment ${ }^{(1-2)}$.

The sub-dimension integrality had its degree of implementation classified as partially implemented, since few cases are referred, either monitored on the conduct and results obtained in other care attention points. Regarding the medical and nursing consultations conducted were observed a better performance by the nursing professional, reaching almost $80 \%$ of the maximum score, which shows gap in the execution of the work in coordination among professionals. It is noteworthy that the DOTS strategy is not focused on the physician, but, along with other professionals, now have a prominent role, especially nurses, coordinating actions, and community health worker in direct contact with the patient and family ${ }^{(18)}$. However, it is necessary to work in an interdisciplinary and coordinated manner, with a view to achieving integrality ${ }^{(10)}$.

In the context of effectiveness of DOTS strategy, that is, the results of treatment, there was no relationship between the degree of implementation and effectiveness of the program. In effectiveness, the classification has not been established, and therefore, PTC has not reached its goal, which should achieve high cure rates and low rates of noncompliance. When individually analyzed (data not shown), almost all BHU gets the final classification as partially implemented, which, does not reflect in the potential success of the program. Therefore, we must think of the DOTS strategy as a whole, and promote actions for its implementation, in order to contribute to the TB control in this high incidence scenario.

\section{CONCLUSION}

The DOTS strategy is an important instrument to corroborate TB control. Nevertheless, it was classified as partially implemented in the BHU studied. It is necessary to emphasize that this is not only to supervise the medication usage, but a set of activities. Although the assessed indicators are below those expected, the potential of viable DOTS strategy for TB control is considered, although it should be implemented according to its assumptions, as well the evaluation can provide directions both for the effectiveness of the strategy as the best way of professional performance. 
RESUMO

Objetivo: Avaliar o grau de implantação da estratégia de tratamento diretamente observado (Directly Observed Treatment, Short-course - DOTS) para tuberculose (TB) em um município de grande porte. Método: Avaliação de implantação por meio de modelo lógico, cujos casos novos de TB pulmonar bacilífera foram recrutados em ambulatórios especializados e acompanhados nas unidades básicas de saúde. Utilizou-se matriz de julgamento que abrange os cinco componentes da estratégia DOTS. Resultados: O resultado do modelo lógico indica DOTS implantada parcialmente. Nos contextos externo, organizacional e de implantação, a estratégia DOTS está implantada parcialmente; e, na efetividade não está implantada. Conclusão: A implantação parcial da estratégia DOTS, na cidade de Manaus, reflete na não conformidade do controle da TB, levando à baixa efetividade do programa.

\section{DESCRITORES}

Tuberculose; Terapia Diretamente Observada; Avaliação em Saúde; Avaliação de Programas e Projetos de Saúde; Enfermagem em Saúde Pública.

\section{RESUMEN}

Objetivo: Evaluar el grado de implantación de la estrategia de tratamiento directamente observado (Directly Observed Treatment, Shortcourse - DOTS) para tuberculosis (TB) en un municipio de gran porte. Método: Evaluación de implantación por medio de modelo lógico, cuyos casos nuevos de TB pulmonar bacilífera fueron obtenidos en ambulatorios especializados y seguidos en la unidades básicas de salud. Se utilizó matriz de juicio que abarca los cinco componentes de la estrategia DOTS. Resultados: El resultado del modelo lógico señala DOTS implantada parcialmente. En el marco exterior, organizacional y de implantación, la estrategia DOTS está implantada parcialmente; y, en la efectividad, no está implantada. Conclusión: La implantación parcial de la estrategia DOTS, en la ciudad de Manaus, refleja la no conformidad del control de la TB, llevando a la baja efectividad del programa.

\section{DESCRIPTORES}

Tuberculosis; Terapia por Observación Directa; Evaluación en Salud; Evaluación de Programas y Proyectos de Salud; Enfermería em Salud Pública.

\section{REFERENCES}

1. Bertolozzi MR, Takahashi RF, Hino P, Litvoc M, França FOS. O controle da tuberculose: um desafio para a saúde pública. Rev Med [Internet]. 2014 [citado 2015 jul. 7];93(2):83-9. Disponível em: http://www.revistas.usp.br/revistadc/article/view/97330

2. Brasil. Ministério da Saúde. Manual de recomendações para o controle da tuberculose no Brasil. Brasília: MS; 2011.

3. Brasil. Ministério da Saúde. O controle da tuberculose no Brasil: avanços, inovações e desafios. Bol Epidemiol [Internet]. 2014 [citado 2015 set. 28];45(2):1-13. Disponível em: http://portalsaude.saude.gov.br/images/pdf/2014/maio/29/BE-2014-45—2—tb.pdf

4. El Kamel A, Joobeur S, Skhiri N, Mhamed SC, Mribah H, Rouatbi N. Fight against tuberculosis in the world. Rev Pneumol Clin. 2015;71 (2-3):181-7.

5. Reis-Santos B, Pellacani-Posses I, Macedo LR, Golub JE, Riley LW, Maciel EL. Directly observed therapy of tuberculosis in Brazil: associated determinants and impact on treatment outcome. Int J Tuberc Lung Dis. 2015;19(10):1188-93.

6. Huynh GH, Klein DJ, Chin DP, Wagner BG, Eckhoff PA, Liu R, et al. Tuberculosis control strategies to reach the 2035 global targets in China: the role of changing demographics and reactivation disease. BMC Med [Internet]. 2015 [cited 2015 Sept 10];13:88. Available from: http://www.ncbi.nlm.nih.gov/pmc/articles/PMC4424583/

7. Oliveira LGD, Natal S, Felisberto E, Alves CKA, Santos EM. Modelo de avaliação do programa de controle da tuberculose. Ciênc Saúde Coletiva [Internet]. 2010 [citado 2013 ago. 3];15 Supl.1:997-1008. Disponível em: http://www.scielo.br/pdf/csc/v15s1/006.pdf

8. Brasil. Ministério da Saúde. Tratamento Diretamente Observado (TDO) da tuberculose na atenção básica: protocolo de enfermagem. Brasília: MS; 2011.

9. Joseph MR, Thomas RA, Nair S, Balakrishnan S, Jayasankar S. Directly observed treatment short course for tuberculosis. What happens to them in the long term? Indian J Tuberc [Internet]. 2015 [cited 2015 Sept 20];62(1):29-3. Available from: http://www.ncbi.nlm.nih.gov/ pubmed/25857563

10. Silva DM, Nogueira JA, Sá LD, Wysocki AD, Scatena LM, Villa TCS. Performance evaluation of primary care services for the treatment of tuberculosis. Rev Esc Enferm USP [Internet]. 2014 [cited 2015 July 15];48(6):1044-53. Available from: http://www.scielo.br/pdf/reeusp/ v48n6/0080-6234-reeusp-48-06-1044.pdf

11. Queiroz EM, De-La-Torre-Ugarte-Guanilo MC, Ferreira KR, Bertolozzi MR. Tuberculosis: limitations and strengths of Directly Observed Treatment short-course. Rev Latino Am Enfermagem [Internet]. 2012 [cited 2015 Sept 20];20(2):369-77. Available from: http://www.scielo. $\mathrm{br} / \mathrm{pdf} / \mathrm{rlae} / \mathrm{v} 20 \mathrm{n} 2 / 21 . \mathrm{pdf}$

12. Hill PC, Whalen CC. Non-clinical factors associated with TB: important for DOTS impact evaluation and disease elimination. Trans R Soc Trop Med Hyg. 2014;108(9):523-5.

13. Nickel DA, Natal S, Hartz ZMA, Calvo MCM. O uso de uma avaliação por gestores da atenção primária em saúde: um estudo de caso no Sul do Brasil. Cad Saúde Pública [Internet]. 2014 [citado 2015 set. 20];30(12):2619-30. Disponível em: http://www.scielo.br/pdf/csp/ v30n12/0102-311X-csp-30-12-02619.pdf

14. Sá LD, Andrade MN, Nogueira JA, Villa TC, Figueiredo TM, Queiroga RP, et al. Implantação da estratégia DOTS no controle da tuberculose na Paraíba: entre o compromisso político e o envolvimento das equipes do Programa Saúde da Família (1999-2004). Ciênc Saúde Coletiva [Internet]. 2011 [citado 2015 set. 20];16(9):3917-24. Disponível em: http://www.scielo.br/pdf/csc/v16n9/a28v16n9.pdf

15. Fraisse P. La tuberculose, le patient, le médecin et la société [éditorial]. Rev Mal Respir [Internet]. 2013 [citado 2015 set 18];30(6):444-5. Disponível em: http://www.em-consulte.com/showarticlefile/819599/main.pdf 
16. Oliveira L, Natal S, Chrispim P. Tratamento Diretamente Supervisionado: estratégia para o controle da tuberculose. Rev APS [Internet]. 2010 [citado 2015 jul. 22];13(3):357-64. Disponível em: http://aps.ufjf.emnuvens.com.br/aps/article/view/612/348

17. Brasil. Ministério da Saúde. Detectar, tratar e curar: desafios e estratégias brasileiras frente à tuberculose. Bol Epidemiol [Internet]. 2015 [citado 2015 set. 2];46(9):1-19. Disponível em: http://portalsaude.saude.gov.br/images/pdf/2015/marco/27/2015-007—-BE-Tuberculose-para-substitui_ $\quad$ o-no-site.pdf

18. Cardoso G, Cruz M, Abreu D, Decotelli P, Chrispim P, Borenstein J, et al. A conformidade das ações do tratamento diretamente observado para tuberculose na perspectiva dos profissionais de duas unidades de saude da cidade do Rio de Janeiro. Cad Saúde Colet [Internet]. 2012 [citado 2015 fev. 2];20(2):203-10. Disponível em: http://www.iesc.ufrj.br/cadernos/images/csc/2012_2/artigos/csc_v20n2_203-210.pdf. 